\title{
Othello'da İlkel Kavramı Bağlamında Gölge Arketipi
}

\author{
Tuğçe Gözde PELİSTER *
}

Özet

İlkel ve gölge, Carl Gustave Jung’un kolektif bilinçdışı kuramının iki önemli ögesi olarak görülmektedir. İnsanlığın ortak ruhsal geçmişindeki bu arkaik unsurlar, batı medeniyetinden çok kabile kültürüne ait unsurlardır. Bu makale, Jung'un ilkel kavramını, içkin olduğu gölge arketipiyle Shakespeare'in Othello adlı oyununda incelemektedir. Makale öncelikle ilkel kavramını batı medeniyeti ve psikolojik boyutuyla tanımlamaya, bu yolla Othello'nun ilkel gölgesiyle olan ilişkisini anlamlandırmaya çalışmaktadır.

Anahtar Sözcükler: Jung, Ilkel, Gölge, Othello.

\section{The Shadow Archetype as Part of The Primitive Concept in Othello}

\section{Abstract}

Primitive and shadow are seen as the two important elements of Carl Gustave Jung's collective unconscious theory. These archaic elements in human's collective psychological past are mainly belong to tribal cultures. This paper analysis Jung's primitive concept which is immanent to shadow archetype in Shakespeare's Othello. Primarily, this paper tries to define primitive concept in the sense of Western civilisation and psychology; in this way, it tries to give a meaning to the relation between Othello and his primitive shadow.

Keywords: Jung, Primitive, Shadow, Othello. 


\section{Giriş}

İsviçreli psikanalist Carl Gustave Jung'un kolektif bilinçdışı ve arketip kuramı, insanoğlunun birbirine zaman ve uzamın ötesinde, insanlığın ortak ruhsal geçmişindeki arkaik unsurlarla bağlandığını öngörmektedir. Kolektif bilinçdışı kısaca, bilincin bastırılmış ya da unutulmuş özü olarak tanımlanabilir. Kişiliğin bilinçli ve merkezi kısmı olan egonun tam tersi olarak da görülebilir. Jung'a göre bilinçdışının yüzeysel katmanı kişiseldir ve Jung, bu katmana kişisel bilinçdışı adını vermiştir. Fakat bu katmanın altında çok daha derin bir başka katman vardır. Bu katman, kişisel deneyim ve edimlerden oluşmaz. Aksine tamamen kalıtsaldır ve Jung, bu katmanı kolektif bilinçdışı olarak tanımlar. Kolektif kelimesini seçmesinin nedeni bu katmanın bireysel değil evrensel özellikler taşımasıdır (Jung, 1968).

Kolektif bilinçdışındaki ruhsal oluşumlar, ancak bilincin algılayabileceği özlerle açıklanabilmektedir. Jung (1968: 4), bu ruhsal ve evrensel özlere arketip adını vermiştir. Bunun sebebini, "bu tabir amacımıza uygundur çünkü kolektif bilinçdışının bizi ilgilendiren özleri eski zamanlardan bu yana evrensel imgeler olarak arkaik ya da ilkel -ben böyle demeyi tercih ediyorum- olarak varolmaktadır” (1968: 5) ifadesiyle açıklamaktadır.

Kolektif bilinçdışı Jung'a göre şeytani özellikler taşımaktadır. Derinlerde, insanın yüzleşmek istemediği ve bastırılmış duygulardan oluşmaktadır. İnsanın bilinçdışının derinlerine dalması ve bu karanlık özelliklerle karşılaşması kolay değildir. Bu yüzden Jung, karanlık özelliklerini reddeden insanın, onları bastırdığını ve farkında olmadan sürekli olarak çevresine yansıttığını ifade etmektedir. Bu karanlık özelliklere gölge arketipi adını vermiştir. "Gölge, insanın bastırılmış, fakat aynı zamanda sürekli belli bir formda yaşamak isteyen canlı bir yanıdır" (Jung, 1968: 20). Yani insan yaşadığı sürece gölgesi de hayatta kalmak isteyecektir.

İlkel ve gölge, kolektif bilinçdışının önemli ögelerinden ikisi olarak kabul edilmektedir. Jung için insanlığın ortak ruhsal geçmişindeki bu arkaik unsurlar batı medeniyetinden öte kabile kültürlerine aittir. Bu bakış açısı arketipsel edebi eleştiri bağlamında Shakespeare'in Othello'sunda ilkel kavramını, Othello'nun geçmişine ait bir analiz konusu haline getirmektedir. Othello'nun batı medeniyeti içinde verdiği ait olma savaşı ve bu savaşta yenilmesini isteyen Iago da oyunda gölge kavramını bir başka analiz konusu yapmaktadır.

Othello önceleri, Jung'çu ve Jung'çu olmayan eleştirmenler tarafından ilkel kavramına az da olsa değinilerek incelenmiştir. Fakat bu analizler, ilkel kavramı merkezinde yapılmamıştır. Barbara Rogers-Gardner (1992: 61), ilkel kavramını Othello'nun zaman kavramı bağlamında ele almış fakat kavramı, Jung'un kuramına başvurmaksızın ortaya koymuştur. Roger-Gardner'ın Othello üzerine yaptığı analizin literatüre yapılmış en önemli katkı olduğunu ifade eden Matthew Fike, ,The Primitive in Othello: A Post-Jungian Reading' adlı makalesinde Jung'un, ilkel kavramını kabile kültürüne dayandırırken bilerek veya bilmeyerek ırkçı bir söylem geliştirdiğini ve bu manada ilkel kavramının düzeltilmeye ve yeniden tanımlanmaya ihtiyaç olduğunu ifade etmiştir (Fike, 2005: 4-11). İlkel kavramını sömürgecilik sonrası edebiyatı çerçevesinde yeniden tanımlamış ve ele almıştır. Roger-Gardner'ın (1992: 39-75) Othello üzerine yaptığı analiz bu makalenin tartışma konusu değildir. Fakat oyunun öyküsünün dışına çıkan ve bazı noktalarda aşırı yorum olarak görülebilecek tespitlerin bulunmasına karşın Roger-Gardner (1992: 66), “Othello'nun, animası (Desdemona) ve gölgesi (Iago) arasında sıkışıp kaldığını" söyleyerek, Jung'un ileride değinilecek olan bireyleşme ve tamamlanma fenomenlerinin gerektirdiği gibi, iç dünyasında ihtiyaç duyduğu tamamlanmaya ulaşıp ulaşmadığını sorgulamıştır. Bunun dışında, Othello, anima-animus (Bodkin, 1934: 219), masum vahşi ve yoz Avrupalı karşıtlığı (Hunter, 1967: 157), uzak ülkelere seyahatleri, Mağribi baba ocağı ve Venedik hayatının tam tersi bir coğrafyadan geldiği fikri (Feldman, 1952: 160), Desdemona'ya karşı olan kıskançlığı ve Desdemona'ya hediye ettiği mendille olan ilişkisi (Aranson, 1972: 27-110) gibi çeşitli açılardan ele alınmış; ancak, yine ilkel kavramıyla direkt olarak ilişkilendirilmemiştir. Fakat ilkel kavra$\mathrm{m}$, daha önce de belirtildiği gibi, tıpkı gölge gibi Jung'un kolektif bilinçdışı kuramının temel ögelerinden biri olarak kabul edilir. Jung bunu (1976: 25), “ilkel ve oryantal psikolojiye karşı uyanan ilgimin kaynağı, kolektif bilinçdışının, bir başka değişle kişilik dışı ruhsal süreçlerin keşfidir” şeklinde ifade etmektedir. Daha birçok akademik çalışma, 
Othello'yu psikolojik katmanlara ayırmış ve karakterleri farklı bakış açılarıyla okuyabilme olanağı tanımıştır. Bu çalışma ilkel ve gölge kavramını Jung kuramı bağlamında tanımlamaktadır. Diğer çalışmalardan farklı olarak, bu iki kavramın Othello'da birbirine içkin olduğunu, Othello'nun yüzleşmesi gereken gölgesinin kabile kültürüne ait geçmişiyle ilişkili olduğunu ortaya koymaya çalışmaktadır.

\section{İlkel Kavramı üzerine}

Steven F. Walker, ilkel kavramının temel olarak iki farklı anlamda kullanıldığını söylemektedir. Bunlardan ilki sanayileşme öncesi ve arkaik kültürlere karşı duygusal bir yaklaşım olarak kabul edilebilir. Walker’a göre (1995: 136-143) bu yaklaşım, hem cahil ilkeli üstü örtük biçimde aşağılamak hem de sömürgeci yaklaşımı "ilkel, ebeveyn gözetimine ihtiyaç duyan bir çocuktur" söylemiyle anlamca ve tavırca azımsamaktır. Bu, batı medeniyetlerinde hala hakim olduğu söylenebilen bir tutumdur. Bir anlamda ilkel, yani kendi normlarına göre medeniyet dışı toplumları, muasır medeniyetler seviyesine çekme sorumluluğu. Matthew Fike'ın yukarıda bahsi geçen makalesine konu olan, bu sömürgeci ve Fike'ın (2005: 5) deyimiyle ırkçı tutumdur. Oysa bu çalışmanın konusu olan ilkel kavramının ikinci anlamı, psikolojinin sınırları içindedir ve idealize edilmiş bir anlamdır. Bu anlam öteki ya da dahası içimizdeki öte$k i$ olarak tanımlanabilir. Bu noktada ikinci anlam batı medeniyeti için dış değil, bir iç düşman haline gelmektedir. Çünkü bu ilkel, modern (batılı) insanın yüzleşmesi gereken ve medeniyet katmanlarıyla örtülü bilinçdışının en derin sembollerinden biridir. Jung'un ifadesiyle (1963: 247) “kolektif bilinçdışının arketipleriyle daha fazla iletişim içindedir”. Bu derin sembolün, modern insanın iç dünyası için dengeleyici bir rolü vardır: İlişkileri, hayal kırıklıkları, beklentileri, kendini kısıtladığı ya da duygularını baskı altına aldığı anların bir dengeleyicisi.

Jung'un kolektif bilinçdışı kuramında, ilkel kavramının tanımı içinde bu iki anlamdan da izler bulunabilir. İki anlamı birbirinden net olarak ayırmak kolay olmasa da içimizdeki öteki, bu çalışmada bir diğer boyut olarak ele alınacak olan gölge arketipinin adeta bir parçasıdır. Gölge, egonun ilkel yoldaşı olarak görülebilir. Çünkü gölge, insanın medeniyetin ya da içinde yaşadığı toplumun olumlamaları doğrultusunda karanlığa gömdüğü dokunulmamış duygularıdır. Fakat karanlıkta kalmış olması yaşamını sürdürmediği anlamına gelmez. Aksine zamanla birikerek bilinçdışı bir varlığa bürünmektedir.

Jung'un hocası Freud'un kişilik modelinin bir parçası olan benliğin, daha çok hayvani ve ihtiyaçlarına göre davranan tarafı id de çoğu zaman ilkel olarak algılanır. İd egonun kontrolü altında bir alandır. Fakat ego tarafından bilinçli şekilde saklı tutulduğu için istenmeyen özellikler ilkel özelliklerle bağdaştırılabilir. Oysa gölgesiyle yüzleşip barışan birey, sıradaki bölümde değinilecek bilinçdışının tamamlanma ve bireyleşme fenomenlerini yaşayarak ruhsal olarak tekrar bir bütün haline gelebilecektir.

\section{Gölge Arketipi üzerine}

Egonun ilkel yoldaşı olarak tanımlamaya çalıştığımız gölge arketipi, bireyleşme sürecinde ilkel kavramı gibi kolektif bilinçdışının ana unsurlarından biri olarak görülmektedir. Bireyleşme, insanın bilinç ve bilinçdışını bütünleştirerek, kendini gerçekleştirme hedefine ulaşması olarak tanımlanabilir. Gölge arketipi bilinçdışının bir parçasıdır. Dolayısıyla bu karanlık taraf bilinçli tarafla bir bütün haline gelmelidir. Aksi takdirde kişi bireyleşme sürecini tamamlayamayacaktır.

Her insanın bir gölgesi vardır. Ya da her gölge bir bedene mi sahiptir? Carl Jung bu soruyu "Sizi yutmuş bir aslanı nasıl bulursunuz?" sorusuyla bir bilmeceye dönüştürmüştür (Jung, 1970: 218-227). Çünkü gölge arketipi doğası gereği bilinçdışıdır. Görmezden gelindiği sürece de bilinçdışı kalmaya devam edecektir. Dolayısıyla insanın, gölgenin karanlık taraflarının yönetimi altında olup olmadığının cevabını, gölgesiyle yüzleşmediği sürece, net olarak vermesi neredeyse imkansızdır. Gölge ilk olarak Sigmund Freud ve Carl Jung'un buluşlarından ortaya çıkan bir kavramdır. Daha sonra Jung Freud'la birlikte başlattığı çalışmayı, insan ruhunun aydınlık ve karanlık tarafları arasındaki ayrımı açımlayan derin bir analize dönüştürmüştür. Jung'un eski bir öğrencisi ve meslektaşı olan Liliane Frey-Rohn (1963: 247), Jung'un, 1912'nin başlarında henüz Freud'un etkisi altındayken farkına varılmayan arzuları ve kişiliğin bastırıımış taraflarını karakterize etmek için "ruhun gölge tarafı" ifadesini kullandığını söylemektedir. Sonrasında 1917 yılında yayımlanan 'On the Psychology of the Unconcious' adlı makalesinde Jung, bireysel gölgeden 
öteki olarak söz eder. Öteki, aynı cinsten bilinçdışı kişilik, ayıplanan alt benlik, bizi utandıran ya da küçük düşüren öteki: "Gölge derken benliğin olumsuz tarafını kastediyorum. Saklamak istediğimiz tüm sevimsiz özelliklerin bireysel bilinçdışıyla birleşmesinin toplamı" (Jung, 1966: 110111). Ayrıca, gölge arketipi her zaman kişisel travmalara ya da çocukluk acılarına da dayanmak zorunda değildir. Aslında temelde onaylanan-onaylanmayan karşıtlığında büyüyüp gelişmektedir. Fakat öncülü Freud'a göre gölge her zaman olumsuz özellikler taşımaz. Aksine bazen toplumun onaylayıp olumladığı şeyler kişi için aşağı ve olumsuz olabilir. Buna rağmen Jung, gölgenin tamamen karanlık, istenmeyen, bastırılmış, ve görmezden gelinenlerin kesişim kümesi olduğunu savunur (1966: 1-118).

Gölge arketipinin karanlık özelliklerini iyi-kötü diyalektiği üzerinden açımlamak mümkün olabilir. Medeniyet sürecinde, doğuştan taşıdığımız özelliklerimizin toplumda kabul görecek yönde evrimleştiğini söylemek yanlış olmayacaktır. İnsanın yaşadığı toplumda kabul görebilmesi tabi ki takdir edilecek bir sonuç olabilir. Fakat kurtulmak istediğimiz özellikler de yok olup gitmemektedir. Bilinçaltının karanlık köşelerinde uzun süre biriktiğinde tıpkı bilinçli yaşam gibi kendine ait bir yaşama dönüşmektedir. "Gölge neredeyse egonunki kadar potansiyel bir enerjiye sahiptir. Eğer bu enerji egonun enerjisinden daha fazla birikirse şiddetli bir öfkeye ya da depresyona dönüşebilir. Kısaca özerk hale gelen gölge, ruhsal dünyamızdaki bir canavara dönüşebilir" (Johnson, 1993: 5).

Gölge arketipi kişisel olmasının yanı sıra kolektif bir özellik de taşımaktadır. Kolektif gölge, kişisel olanın aksine bazen geniş bir topluluk hatta bütün bir ulusun kötülük arketipinin gücü altında kitlesel bir özelliğe bürünebilir. $\mathrm{Bu}$ durum, participation mystique olarak bilinen bilinçdışı bir süreçle açıklanmaktadır. Lucien Lévhy-Bruhl'ün kullandığı, Türkçe, 'gizemli ortaklık/birliktelik' anlamına gelebilecek bir ifadedir. Jung bu ifadeyi 'Psychological Types' (1971: 398-403) adlı makalesinde temel tanımlardan biri olarak kullanır: "Participation Mystique, Lévy-Bruhl'den alınmış bir kavram. Kavram, nesnelerle kurulan olağandışı psikolojik bir bağı ifade eder, ve öznenin kendini bu nesneden net bir şekilde ayırmaksızın kısmi bir kimlik geliştirmesi ve nesneyle doğrudan bir ilişkiye girmesine dayanır”. Jung'un bu tanımında bağlanılan nesne, bir kişi ya da bir fikir de olabilmektedir. Bu noktada kişi duygulara dayalı kurduğu bu ilişkiyi, ahlaki bir değerlendirmeye tabi tutamamaktadır. Participation Mystique, "Kolektif gölge söz konusu olduğunda, toplumun genelinin korku ve aşağılık duyguları$\mathrm{nl}$, bir ideoloji ya da bir liderin anlamca belirlemesidir. $\mathrm{Bu}$ durum genellikle dini zulüm, ırkçı yobazlık, sınıf sistemi, günah keçisi ilan etmek, cadı avcılığı ya da soykırım nefreti gibi fanatik tutumlara dönüşür. Toplumun reddettiği gölgeyi taşıyan bir azınlık söz konusu olduğunda, ciddi bir kötülük potansiyeli açığa çıkar” (Abrams, J., Zweig, C., 1990: 167). Anlaşıldı̆̆ı gibi kolektif gölge, kişisel gölgeden daha geniş etki alanı olan bir yapıdadır. Kolektif gölgenin, batı medeniyetinin ilkel olanı belirlemesinde etkili olduğu söylenebilmektedir.

İnsan, dünyaya bedensel ve ruhsal bir bütün olarak gelmiştir. Fakat toplum, ironik olarak insanın bu bütünün tek bir tarafını yaşamasına izin vermektedir. Bu baskı insanın kendisini ego ve gölge olarak ikiye bölmesine sebep olmuştur çünkü medeniyet tek bir biçimde davranması konusunda ısrarcıdır. Kısaca medeni toplumsal yaşayış içimizdeki basit insanı alıp yerine daha karmaşık ve gelişmiş bir insan vermiştir. Othello'daki ilkel kavramı ve içkin olduğu gölge arketipi, insanoğlunun medenileşme sürecinde, toplumsal ideallerin işleyişinin dışında kalmıştır. Bu sürece dahil olmayan her kim olursa bir ilkel olarak, artık bu görgülü ve kültürlü toplum (Venedik toplumu) yaşantısının dışında kalacaktır. Daha dikkat çekici olan şey iyi-kötü olarak kabul gören ya da görmeyen özelliklerin, dünyanın her yanında kültürel olarak ciddi farklılıklar göstermesidir. Bu farkların ortaya çıkaracağı sonuçlar bir başka çalışmanın konusudur. Fakat en net ayrımlardan biri olan doğu-batı Othello'da ilkel kavramı ve gölge arketipi için belirleyici bir ayrım olarak izlenecektir.

\section{Venedik Toplumu ve Kolektif Gölge}

Shakespeare'in Othello adlı oyunu, gölgenin karakterlerini saldırıya geçirdiği bir oyun olarak değerlendirilebilir. Shakespeare oyunlarında karakter, saldırgan (genelde kendini yok etmek üzere) durumuna geçmektedir (Şener, 2003: 68-82). Çatışma, Othello ve Desdemona'nın aralarındaki yaş ve ırksal farklılıklara rağmen evlenmeleridir. Evlilikleri istediği mevkiye ulaşamayan Iago'nun intikam 
için Othello'yu Desdemona'nın sadakatsiz olduğu yalanına inandırmasıyla trajediye dönüşür. Bu trajedinin ardında Othello'nun ve Venedik toplumunun karanlık taraflarının olduğu söylenebilir.

Othello Mağripli bir komutan olarak Venedik soyluları arasında askeri becerileriyle sayg duyulan erdemli bir adamdır. Aslında yaşadığı toplumun doğuştan bir parçası değildir. Kabul görmek ve onaylanmak -belki de Venediklilerden bile çok- en büyük arzusudur. Othello'nun sonunda Desdemona'yı öldürecek kadar kendini kaybetmesi Othello'nun bastırdığı aşağılık duyguları ve yaradılış özellikleri olarak okunabilir. Othello erdemli ve iyi kalpli olsa da karakteri yaşadığı toplumun değer yargılarına göre şekillenmiş bir adam değildir. Toplum ona değil o yaşadığı topluma uyum sağlamak için çaba göstermiştir. Bunu da Venedik toplumunda askeri becerileriyle ön plana çıkarak gerçekleştirmiştir. Othello'nun Venedik toplumunda yerini belirleyecek en önemli özellikler nezaket, kontrollü olmak ve güç olarak tanımlanabilir. Aksi şekilde kaba, vahşi ya da zayıf davranışlar sergilemek itibarını yok edecektir. Bu sebeple Othello'nun gölge yanı birçok kere söylendiği gibi (Bodkin, Aranson, Rogers-Gardner) tek başına Iago karakteri olarak tanımlanamaz. Iago aynı zamanda Venedik ve dolayısıyla batı toplumunun bir temsilcisi olarak, Othello'yu karanlık yanlarıyla yüzleşmek zorunda bırakacaktır. Othello, gölgesinin farkında olmayan bir karakter değildir. Aksine burada sürekli bir kişisel kontrol söz konusudur. Iago ise, bu erdemli adamın kontrol altında tutmaya çalıştığı duyguları serbest bırakır. Fakat hızlı bir sonuca varmadan önce yukarıda açımlamaya çalıştığımız ilkel kavramı ve gölge arketipinin oyunun alt metinine nasıl farklı bir bakış açısı getirdiğini anlamaya çalışmak gerekmektedir.

Öncelikle Mağripli Othello'nun, yaşadığı Venedik toplumunda nasıl algınlandığı, ilkel kavramını kolektif gölge bağlamında anlamlı kılmaktadır. Oyun, Venedikli bir beyefendi olan Roderigo ve Iago'nun konuşmasıyla başlar. Roderigo Desdemona'ya aşıktır. Iago, Roderigo'ya Desdemona'nın Othello'yla kaçarak gizlice evlendiği haberini verir. Bu esnada Othello'nun, kendisi yerine Floransalı Cassio'yu yaver olarak seçtiğini anlatır. Iago oldukça kızgındır. Cassio'yu, askerlikten anlamayan ve kafası sadece para işlerine çalışan biri olarak aşağılar. Bu sırada Roderigo Mağripli için "0 kalın dudaklı herif kızı böyle kaçırabildiyse, ne zengin bir hazineye kondu, düşünsene" (Shakespeare, 2013: 3) der. Othello'nun ırksal özelliklerine bir göndermedir bu. Desdemona'nın babası Brabantio soylu bir senatördür. Roderigo ve Iago, Brabantio'yu Desdemona'nın gizli evliliğini açıklamak için evinin önünde bağırarak uyandırırlar ve evlilik haberini verirler. Brabantio yıkılır ve bu habere inanmak istemez.. Iago Brabantio'yla arasında geçen konuşmada Othello için 'kocamış kara koç, Berberi Küheylanı' gibi sıfatlar kullanır. Desdemona'ya ise 'ak koyun' der. (Shakespeare, 2013: 4-5). Bunlar, Othello'nun ten rengine dayanan hakaretlerdir. Brabantio'nun iki yüzlülüğü ilgi çekicidir. Kızının Mağripliyle nasıl evlendiğine anlam veremez. Oysa Othello'yu defalarca askerlik maceralarını anlatması için evinde konuk etmiştir. Zaten Desdemona da bu ziyaretler sırasında Mağripli'ye aşık olmuştur. Fakat şimdi Othello’yu aslında nasıl gördüğünü açıkça belli etmektedir:

BRABANTIO: Seni aşağılık hırsız, nereye tıktın kızımı? Büyüledin onu, lanetli olman yetmezmiş gibi!

Aklı başında olan herkese sorarım:

Büyüyle zincirlenmiş olmasaydı eğer

Onun gibi nazlı, güzel, mutlu bir kız,

Hiç geri çevirir miydi ülkemizin zengin

yakışıklı delikanlılarını

Bırakır mıydı onu koruyan babasını,

Sonra da göze alıp herkesin maskarası olmayı,

Senin gibi zevk yerine korku veren bir herifin

Kurum karası kucağına kaçar mıydı?

Bütün dünya hak versin, apaçık değil mi her şey?

Onu tuzağa düşürüp pis büyüler yaptın,

Kendini kaybettirecek ilaçlar, şuruplar içiri

[kıydın gençliğine, (Shakespeare, 2013: 12).

Brabantio'nun evine kabul ettiği bir kişiyi fikren onaylaması beklenirken, o farklı bir tepki verir. Branbantio, Othello'yu kendi belirlediği sınırlar içinde kabullenmiştir. 0 sınırların dışına çıktığında tavrı büsbütün değişmiştir. Bu sırada Venedik Osmanlı İmparatorluğuyla savaştadır. 
Venedik dukası bu olay esnasında senatoyu toplar. Kıbrısa gitmek üzere Othello'yu görevlendirecektir. Duka tarafından çağrılan Branbantio Dukanın da bu meseleyi bilmesini ister. "Eminim, hissedecekler bu haksızlığı kendilerine yapılmış gibi, Böyle hareketler hoş görülürse eğer, Devletin başına kölelerle dinsizler geçer” (Shakespeare, 2013:13). Burada diğer Venedikli senatörlerin kendisiyle aynı fikirde olacağından emindir. Köle ve dinsiz sözleriyle Othello'yu hedef alır. Othello, geçmişte köle olarak satılmış ve sonra serbest bırakılmıştır. Brabantio'nun evinde konuk olduğunda geniş mağaralarda, ıssız çöllerde geçen maceralarını anlatmıştır. Şimdi Brabantio bu hikayeleri silah olarak kullanmaktadır. Dinsizler derken Müslümanlığı mı yoksa derisinin rengi yüzünden kabile kültürüne ait inananışları kastederek mi Othello'yu aşağıladığı açık değildir. Fakat daha önceki sözlerinde büyü ve şurup kelimelerini kullanmıştır. Bu bağlamda daha çok, medeniyet dışı kabile kültürlerini kastederek konuştuğu söylenebilir.

Bu noktada bir parantez açıp, Jung'un ilkel insanı fiziksel özellikleriyle de tanımlama girişimlerinin olduğunu söylemek gerekir. Biz bu çalışmada ilkelliğin ruhsal ve bilinçdışı süreçlerini göz önünde bulundursak bile Jung'un ilkel kavramı önceden belirtildiği gibi çift anlam taşımaktadır. Jung "psikolojik olarak ilkel insan daha çok kabile kültürlerine aittir. Kabile insanları siyah ve kırmızı derilidir. Dolayısıyla siyah ve kırmızı derili insanlar ilkeldir" (Fike, 2005: 6) gibi oldukça matematiksel bir sonuca varmak istemiş gibidir. Jung'un bu söylemleri, çoğu kişi için maksadını aşan, ırkçı ve sömürgeci bir tavır olarak değerlendirilebilir. Fakat 'Archaic Man' adlı makalesinde ilkelin, ten rengini değil aksine "insanın ruhsal dünyasını, bilinç durumunu ve yaşam şeklini” (Jung, 1970: 54) ifade ettiğini de belirtmiştir.

Parantezi kapatıp kaldığımız yerden devam edersek Brabantio, oyunun genelinde çok etkili bir karakter değildir. Fakat kolektif gölgesini Othello'ya yansıtan bir batılı örneği olarak önemlidir. Venedik, batı medeniyetinin merkezlerinden biridir. Arap toplumu ise, batı medeniyetiyle aynı seviyede değildir onlara göre. Dolayısıyla uzak ülkelerde Venedik için savaşan bir Othello, konu gerçekten onu aralarına almaya geldiğinde istenmeyen ötekine dönüşmektedir. Bu noktaya kadar Othello’nun kökenlerini öteki- leştiren üç karakter söz konusu olmuştur. Roderigo, Branbantio ve Iago. Siyah derili insanlar ve kabile kültürü gibi olgular, batı medeniyetinin yansıttığı ırksal bir kolektif gölge olarak görülebilir. Jung (1970: 66), “herkesin bilinçaltında bir siyah derili yaşar. Nasıl yahudilerin hıristiyan kompleksi varsa, her siyah derilinin de beyaz kompleksi vardır. Tabii her beyazın da siyah kompleksi söz konusudur. Genellikle siyah adam ten rengini değiştirmek için her şeyini verir ve beyaz adam da siyah adamdan etkilendiğini kabul etmekten nefret eder" der. Bu ifade her insanın, arkaik formundan gelişmiş olana doğru evrilme güdüsü içinde olduğunu düşündürmektedir. Beyazların, kendilerini gelişim sürecinde piramidin en üstüne yerleştirmesi de bu algıyı doğurmuş olabilir. Fakat ne olursa olsun Jung'un ifadeleri, insanın kendi gölgesiyle yüzleşmesinin zorluğunu vurgulamaktadır.

Son olarak Othello'nun yazıldığı dönemin toplumsal durumuyla ilgili Leslie A. Fiedler'ın tespitleri dikkat çekicidir. Fiedler, Othello'nun yazıldığı dönemde Yeni Dünyanın çoktan keşfedildiğini ve seyircinin 'kabile,1 kelimesini sadece Yahudilerle değil aynı zamanda altına ve değerli taşlara düşkünlükleri yüzünden küçük görülen yerlilerle de ilişkilendirmeye başladığını söylemiştir (Fiedler, 1972: 196). Bu bilgi Shakespeare seyircisinin yanı sıra, yazar Shakespeare'in de oyunu yazarkenki bakış açısı hakkında fikir verebilir. Shakespeare de batı medeniyetinin bir parçasıdır ve toplumla aynı kolektif bilinçdışını paylaşır. 0 dönemde günümüzde hakim olan politik doğruculuk söz konusu değildir. Toplum dinsel, ırksal ya da politik manada tecrübelere dayalı sözel kısıtlamalarla tanışmamıştır. Dolayısıyla geniş bir alımlayıcı kitlesine ulaşan bir metnin, bilinçli bir politik söylem geliştirme ihtimali düşük kabul edilebilir. Fakat kolektif bilinçdışının arketipsel (gölge) gücü, azımsanmaması gereken bir etkidir. Medeni olanla içgüdüsel olarak kurulan güçlü bağ (Participation Mystique), azınlıkta olanı kolayca ötekileştirmeye sebep olur. Bu durumun, Shakespere'in oyundaki karşıtlığı kurgulamasında etkili olduğu söylenebilir.

\section{Othello ve İlkel Kişisel Gölge}

Önceki bölümde görüldüğü üzere Türkler’le savaş, kabile kültürüne ait büyü, şurup, lanet gibi doğaüstü güçler oyunun toplumsal psikolojik durumu için bir yorum imkanı ya- 
ratmıştır. Bu durum Othello'nun kişisel gölgesiyle savaşı ve trajik sonu bağlamında tetikleyici bir unsur olmuştur. Çünkü Othello ilk olarak Iago'dan, Brabantio'nun ondan hesap sormaya geleceğini duyduğunda kendini onaylama ihtiyacı duymuştur:

OTHELLO:Elinden geleni ardına koymasın.

Onun şikayetleri hiç kalır devlete yaptığım [hizmetler yanında

Henüz kimse bilmiyor: Böbürlenmenin şeref olduğunu [gördüğümde ama,

Krallar yetiştirmiş bir soydan geldiğimi açıklayacağım.

Bugün erişmiş olduğum, gurur ve yüksek makamı

Gösterdiğim büyük başarılara borçluyum yalnızca (Shakespeare, 2013: 9).

Başarılarıyla kabul gördüğünün farkında olan Othello kendine güvenmek ister. Branbantio tarafından istenmeyişinin sebebinin farklı soydan gelmesi olduğunun farkındadır. Aynı zamanda Venediklilerin kendilerini övmeyi şereften saydığını da anlamıştır. Fakat kendi soyunun utanılacak değil aksine gurur duyulacak bir soy olduğunu söyler. Eğer geldiği yere sahip çıkarsa ve bununla övünürse şerefli bir erkek olacaktır. Belki de bu fikre yürekten inanmış olsaydı Desdemona'yla sonu bambaşka olacaktı. Fakat Othello, yaşanacak olaylara karşı sandığından çok daha zayıf olduğunu anlayacaktır.

Othello'nun karşıt kişisi olarak Iago ve tamamlanması için bir firsat olan Desdemona da Venedik toplumunun sembolleri olarak yorumlanabilir. Iago Venedik'in ilk reddini Othello'ya bildiren kişidir. Othello cevabını Iago'ya yani Venedik toplumuna yukarıdaki sözleriyle vermiştir. Othello, Venedik yaşantısında askeri başarılarının yanı sıra, o toplumun bir parçası olan Desdemona'yı kendine aşık etmiştir. Bu da Othello için toplumsal manada bir zafer olarak kabul edilebilir. Çünkü artık sadece Venedik için uzak ülkelerde savaşan, kendini tehlikeye atan bir Mağripli komutan değil aynı zamanda tercih edilen bir eş olma fırsatı da yakalamıştır. Peki burada yolunda gitmeyen ne olmuştur? Iago'nun kışkırtmalarını sorgusuzca boyun eğmesi Othello'nun, tamamlanma ve bireyleşme yolunda attığı yanlış bir adım olarak değerlendirilebilir mi?
Bu noktadan sonra Othello'nun Iago'yla girdiği ilişki, ve Iago'nun olayları yönlendirmesi önem kazanmaktadır. Othello'nun medeniyet karşısında verdiği mücadele bu ilişkidir. Öncelikle Iago, Othello'yu kıskandırmak için Cassio gibi Floransalı bir beyefendiyi seçmiştir. Oysa Cassio'dan hoşlanmamaktadır. Fakat Cassio, fiziksel ve toplumsal değerler manasında Iago'ya göre Othello'dan üstündür. “Cassio karısıyla sıkı fıkı diye çıtlatırım Othello’ya. Zaten Cassio şüphe uyandıracak kadar yakışıkl, tüm kadınların gönlüne göre." (Shakespeare, 2013: 28). Ayrıca, Othello'nun da bu üstünlüğün farkında olduğunu sezmektedir. Bunu silah olarak kullanacaktır. Cassio'yu bir sarhoş kavgasına sokar. İtibarı zedelenen Cassio'yu Othello yaverlik görevinden alır. Desdemona'dan yardım isteyen Cassio'nun isteğini geri çevirmez. Iago, Desdemona'nın Cassio'yu affetmesi için Othello'yu ikna ettiğini gördüğünde düğmeye basar. Şüphe tohumunu eker. Cassio ve Desdemona arasında birşey olduğu konusunda Othello'nun kafasını karıştırır. Oyunda Iago ve Othello'nun karşı karşıya kaldığı, mendil meselesinin ortaya çıktığı ve Othello'nun kendi içinde savaş verdiği sahne III. perdenin III. sahnesidir (Shakespeare, 2013: 62-85).

Oyunda kıskançlık temasının ön planda olması Othello'yu basit bir kıskançlık trajedisi yapmaz elbette. Burada insanın karanlık tarafıyla yaptığı soğuk ve sert bir savaş söz konusudur. Iago, Desdemona'yla ilgili şüpheleri olduğunu ima ettikten sonra, Othello'nun daha ilk andan telaşla ve şüpheyle Iago'yu sorguladığı görülür. Iago'nun dürüst olduğuna inandığı için ondaki tedirginliği şüpheyle yorumlar. Aslında gerçekten Iago'nun dürüst bir adam olduğundan emin olacak bilgiye sahip değildir. Anlık ve içgüdüsel kararlar alır. Adeta ona inanmaya hazırdır. Cassio'nun, çok güvendiği bir yaver olduğu düşünüldüğünde bir kavga yüzünden sorgusuz görevine son verişi de benzer fevriliktedir. Coşkulu, tutkulu, bir anlamda agresif bir karakterdir Othello. Aynı zamanda vahşidir. Ruhunda eğitemediği ilkel kalan bir taraf vardır. Hemen tepki vermeye hemen parlamaya hazırdır. Adeta küçük bir çocuk gibidir. Iago, Desdemona’nın babasını da yüzüstü bıraktığını hatırlatır Othello'ya II. Perdenin II. sahnesinde. Othello'yla evlenmek için babasının itirazları karşısında nasıl kayıtsız kaldığını söyler. 0 kadar isabetli bir hamledir ki kötülüğün 
ve şüphenin tohumu atılır. Çünkü Iago'nun da Othello'nun da aklına bu zehir ilk kez Brabantio Othello'yu "babasını aldatan seni de aldatır" (Shakespeare, 2013: 24) diyerek uyardığında girmiştir. Bu anlamda Iago'nun işi o kadar da zor değildir. Sadece ufak bir hatırlatma fitili ateşlemeye yeter. Brabantio'nun onayının Othello için tetikleyici özelliğinden bahsetmiştik.

Şimdi Othello, ilkel duygulardan oluşan gölgesini yansıtacak birine ihtiyaç duymaktadır. Bu kişi Desdemona'dan başkası değildir. Askeri gücünü ispat etmiş fakat Desdemona tarafında eksik ve çaresiz kaldığına inanmaya başlamıştır. Ayrıca Desdemona'yla gerçekten karı koca gibi yaşayacak zamanları da olmamıştır. Bir anlamda Othello'nun cinsel manada Desdemona'yla tam bir bütünlük içine girememesi de ilkel duygularını olumsuz yönde harekete geçiren bir etken olarak görülebilir. Bazı araştırmacılara göre Othello'nun Desdemona'yla cinsel olarak birleşip birleşmediği bir muammadır. Lynda E. Boose, Barbara Roger-Gardner birleştiklerini düşünürken; Peter L. Rudnysky ve T.G.A. Nelson ve Charles Haines, çiftin cinsel manada birleşmediğini düşünmektedirler. Jung'un seksüel libidoya bakışı bu konuyu ilkel kavramı bağlamında aydınlatabilir (1970: 69): "libidonun kullanılmaması onu kontrolden çıkarır", "Sürekli görmezden gelindiği için biriken bilinçdışı ögeler patolojik bir duruma dönüşebilir. Medeni Avrupalı'lar arasında olduğu kadar ilkellerde de nevrotik kişiler mevcuttur". Othello askeri zaferini kazanmış fakat Desdemona'yla baş başa kalacak vakit bulamamıştır. Şimdi bu bastırılmış duygular olumlu bir ilişkiye dönüşemeden Iago tarafından şeytanca bir şüpheye yönlendirilmektedir. Aslında Iago'nun yaptığı şey Othello'nun zihninde Desdemona'yı bu şüphe perdesinin ardından görmesini sağlamaktır.

Jung (1995: 45-58), bir kişinin gölgesiyle barışmasının tek yolunun karşı cinsle ilişkilenmek olduğunu ifade eder. Oysa Othello, bu yolun yakınında bile değildir. Othello, Desdemona'nın naif, yumuşak, evcil ve sevecen doğasını kabullendiğinde, kendi içindeki katı ve kontrollü tarafı yumuşatma şansını elde edebilecektir. Iago'nun kendisini baştan çıkarma girişimlerine sorgusuz sualsiz inanmayıp Desdemona'yla konuşma yolunu tercih de edebilirdi elbette. Ama Othello'nun doğası böyle davranmasını engeller. Iago, Othello'nun ilkel ve bir anlamda karşı cinse karşı olan mülkiyetçi güdülerini ortaya çıkarmaktadır. 0 halde, tamamlanmak için gölgesiyle barışmak zorunda olan bir birey olarak Othello, kendine karşı olan sorumluluğunu yerine getirmediği için bu görev bir anlamda Iago'ya düşmüştür. Othello, gölgesiyle barışma şansını kaçırmak üzeredir. Iago üsteledikçe Othello, içinde hazır olan fakat görmezden geldiği duyguları kolaylıkla salıverir. Fakat bu azad onun için trajik olacaktır. Iago'nun her hamlesi adeta Othello'ya aslında Othello'nun gerçekte ne olduğunu hatırlatmak içindir. "Olur a, bir gün eskiye döner de, kendi soyundan erkekleri canı çeker belki, sizi kendi ülkesinin erkekleriyle karşılaştırır diye kaygılıyım hani” (Shakespeare, 2013:74) diyerek Othello'ya Mağripli oluşunu hatırlatır. Othello'nun bu sözler karşısında yavaş yavaş kendi gölgesine yenilmesini şu sözleri ortaya koymaktadır:

OTHELLO:...Evet karayım belki. 0 kibar züppeler gibi

Bilmiyorum konuşma inceliklerini

Çok olmasa da, inmeye başladım ben

Ömrümün basamaklarını

Belki de onun için uçmuştur elimden (Shakespeare, 2013:75).

Othello onlara benzemek için çabaladığı soylulara züppeler der. Aslında bunlar kendi düşünceleridir ve yavaş yavaş bilinçdışından dışarı sızmaya başlamıştır. Konuşma inceliklerini bilmediğini söyler oysa ki konuşma sanatına hakimdir. Desdemona'nın kalbini de bu yeteneğiyle çalmıştır. Şimdi Desdemona'yı kaybettiğini düşünmektedir. Karısının üzerindeki olumlu etkisini kendisi küçümsemeye başlamıştır. Hatta yaşlandığını, karısını da bu yüzden kaybettiğini düşünmektedir. "Çok olmasa da, inmeye başladım ben ömrümün basamaklarını, belki de onun için uçmuştur elimden" diyerek Othello, lanet eder aldatılmasına. Oysa Othello'yu bu duruma getiren bilgilerin gerçekle alakası yoktur. Iago'nun karısı Emilia Desdemona'nın hizmetindedir. Iago, Othello'nun Desdemona'ya hediye ettiği mendili Emilia'dan çalmasını ister. Amacı, mendili Desdemona ve Cassio'nun hayali ilişkisinin bir kanıtı olarak Othello'ya sunmaktır. Çünkü Othello, her ne kadar Desdemona'dan şüphelense de ısrarla ve öfkeyle Iago'dan bir kanıt istemektedir. Desdemona'nın şans eseri mendili düşürmesi Iago'ya bu şansı verir. Emilia'nın nedenini bilmeksizin 
mendili Iago'ya vermesi olayları çığrından çıkaracaktır. Belki de mendil olmasa Iago, Othello'yu uydurduğu yalana inandıramayacaktır. Iago, mendili Cassio'nun elinde gördügünü söyler Othello'ya. Othello'yu bu noktadan sonra durdurmak imkansızdır. Çünkü köklerine yenik düşecektir. Kabile kültürüne özgü doğaüstü güçler, büyü ve inanışlar batının ilkellikle bağdaştırdığı özelliklerdir. Branbantio örneğinde de net olarak görülmüştür. Othello'nun bastırdığı ve görmezden geldiği bu özelliklere artık hakim olamadığı izlenir. Desdemona'dan mendili ister. Desdemona, mendile ne olduğunu açıklayamayınca mendille ilgili hikayeyi anlatır. Artık Othello'nun ruhunu bu hikayenin laneti ele geçirmiştir.

OTHELLO: ...0 mendili bir çingene vermiş anneme.

Bir büyücüymüş, insanın aklından geçenleri [okuyabilirmiş hemen.

Anneme, bu mendili yanında tuttuğu sürece,

Kocasının ona aşık olup bağlı kalacağını,

Ama onu kaybederse ya da armağan ederse birine,

Babamın gözünden düşeceğini

Babamın da yeni aşklar peşinde koşacağını

Söylemiş (Shakespeare, 2013: 88).

Jung (1976: 5-35), ilkellerin yaşamdaki tüm olayları birtakım törensel durumlarla özdeş kıldığını, bunun insanın 0 andan kopup, ruhsal enerjisini hayatının sıradaki evresine aktarmasına yardımcı olduğu ifade etmektedir. Othello, gölgesini oluşturan ilkel enerjiyi, o anda annesinin ona verdiği mendile yönlendirmiştir. Onu sahiplenmiş, geçmişinin ve annesinin bir sembolüne dönüştürmüştür. Gereğinden fazla kurduğu bu derin bağ adeta gözlerini karartmıştır. Mendilin Othello'nun ruhunda böylesi bir hakimiyeti söz konusu olmuştur. Ayrıca Othello, Venedik'ten gelen bir mektupla, Venedik'e geri çağrıldığını ve yerine Cassio'nun geçeceğini öğrenir. Othello için Cassio, hem karısını hem de görevini elinden alan bir düşmandır. Desdemona Cassio'nun görevlendirilmesine safça sevindiğinde Othello ona bir tokat atar. Oysa Desdemona, olayların ardında akla yatkın bir sebep arama eğilimi gösteren bir karakterdir. Othello'nun hiddetle kendisine attığı tokattan sonra bile, onun devlet işlerine sinirlenmiş olabileceğine inanmaktadır.
Mektubu getiren Brabantio'nun bir akrabası Lodovico'dur. Othello'nun Desdemona'ya attığı tokadı görmüştür. Şimdi Othello, karşısında güçlükle ayakta durduğu tüm medeni değerler karşısında bir vahşiye dönüşmüştür:

LODOVICO: Bütün senato üyelerinin her açıdan yetenekli bulduğu

Soylu Mağripli bu ha! Duygunun sarsmayacağı adam bu mu?

Kararlı, sağlam karakterinin kaza kurşununun öldüremeyeceği,

Talih okunun yaralayamayacağı adam bu demek? (Shakespeare, 2013: 109)

Othello'nun Venedikli soylularca nasıl görüldüğü, onun bu zamana kadar kazandığı itibarı açıç̧a ortaya koymaktadır. Aynı zamanda nasıl gözden düştüğünü de. Önceden kaybetmemesi gereken özelliklerin nezaket, kontrollü olmak ve güç olduğunu ifade etmiştik. Fakat Othello, bunların hepsini tek bir tokatla kaybetmiş gibi gözükmektedir.

\section{Sonuç Olarak Othello}

Othello, son noktada ilkel gölgesi tarafından tamamen ele geçirilmiştir. Desdemona'nın kendisini aldatan bir şeytan olduğuna inanmaktadır. Egosu, gölgesi üzerindeki tüm hakimiyetini kaybetmiştir.

OTHELLO: Ama ölmeli, yoksa baştan çıkarır bütün erkekleri.

Işık sönsün, sonra da sönsün ışı̆̆ı! (Shakespeare, 2013: 137).

Jung'a göre ilkel olarak görülen toplumları anlamaya çalışmak çoğu zaman kör olduğumuz kolektif gölgemizi görmenin kolay yoludur. Othello'nun kişisel gölgesi, kolektif gölgenin bir yansımasıdır. Toplum, gölgesini ona yansıtmış, yansıttıkça Othello kişisel aşağılık duygularını da ekleyerek kendi karanlığını inşa etmiştir. Bu sürecin ardından, Othello da insanın ilk halinden oldukça uzaklaşmış gibi görünmektedir. Ne de olsa insan Jung'a göre, yaratılışın bir parçasıdır. "İnsan, yaratılışın sürecinin tamamlanmasında hayati rol oynar... aslında, dünyaya nesnel varoluşunu sunan yegane varlık olarak kendisi, dünyanın ikinci yaratıcısıdır" der Jung (1963: 256). Othello kendi yaratıış 
(bireyleşme) sürecini kolektif gölgenin karanlığında bir anlamda erteleyen bir karakterdir. Kendisi bu görevi üstlenmediği içindir ki Iago'ya teslim olmuştur. Baştan beri Othello'nun Iago'nun sözlerine kanmak için hazır olmasının sebebi budur. Ayrıca Iago'nun da bir anlamda Othello'ya muhtaç olduğu söylenebilir. Çünkü Iago her ne kadar batı toplumuna ait olsa da tamamlanmak için kendine ait yöntemler geliştiren sıradan bir insandır. İçindeki kötülükle elbette Othello sayesinde karşılaşmaz fakat entrika ve kötülükten başka birşey düşünmeyen insan olarak gelişimini ruhsal değil materyalist değer yargıları üzerinden tamamlamaya çalışır. Aslında Othello'yla aynı anda kendisinin de sonunu hazırlar.

Jean-Marc Pottiez'le yapılan 'A Walk With a White Bushman' başlıklı kışkırtıcı röportajında Jung'un eski bir arkadaşı olan Sir Laurens van der Post, ilkel kültürle olan engin deneyimlerini paylaşır. Bu Kalahari çölünde yaşayan ve "ilkel” olarak nitelenen Afrika halkıyla ilgili araştırmaları sonucu ortaya çıkan en çarpıcı ifadesi "Bushman'lere verdiğimiz en büyük hasar içimizde yaşayan Bushman’lere verdiğimiz hasardır. Çünkü başka bir insana yaptığınız şeyi aslında kendinize yapmış olursunuz" şeklindedir (Van der Post, 1988: 29). Aynı röportajda Jung, Bushman'lerin kişisel farkındalıklarının olmadığını söyler. Zekalarının ilkel ve vahşi kaldığını ekler. Fakat bu zeka durumu onların akıl yerine içgüdüleriyle hareket etmelerini kasteden sözlerdir.

Othello'nun son hali medeniyet ve vahşilik arasında bir yerde sıkışıp kalmıştır. Öldürmeye yatkın doğası onu Venedik'te başarılı bir asker yapmış olsa da aynı ilkellik Desdemona'nın canını almasına sebep olmuştur. Yaşadığı ruhsal süreçler üzerinde akıl (ego) yoluyla hakimiyet kuramamıştır. Son sözleri gölgesini anlatan cümlelerdir. Belki de ilk defa Iago'nun sözlerinin bir anlamı vardır, “Göründükleri gibi olmalıdır insanlar/eğer değillerse göründükleri/insan değil şeytandırlar.” (Shakespeare, 2013: 69).

OTHELLO: Nasılsam öyle söz edin benden.

Hiçbir şeyi hafifletmeyin, ama hiçbirini de

Anlatmayın kötü niyetle.

Benin için, akılsızca ama çok seven biri deyin,

Kolayca kıskanmayan, ama bir kez de kıskandı mı
Kendini kaybeden biri diye söz edin benden.

O deyin, aşağılık bir Hintli gibi,

Kendi kavminden daha değerli bir inciyi

Firlatıp attı.

Alışık değildi ağlamaya, ama tutsak olunca gözleri,

Arabistan ağaçlarının her derde deva zamkı kadar çok göz yaşı döktü.

Böyle yazın nokta.

Şunu ekleyin sonra:

Bir gün Halepte dolaşırken

Rastlamıştım zorbalık eden bir sarıklıya,

Bir Venedikli'yi dövüyor, devlete küfrediyordu,

Gırtlağından yakalayıp sünnetli köpeği

Gebertmiştim... İşte böyle.

(Kendini hançerler) (Shakespeare, 2013: 156).

Göründüğü gibi anılmak ister Othello. Görünmeyen tarafının farkına varmıştır. Fakat ölürken bile Venedik için kıymetli kalmak ister. Belki de tek avuntusu budur. Onaylanmama korkusunun hayatının ve duygularının kontrolünü ele geçirmesine izin verir. Burada şeytani olandan söz edilecekse gerçek şeytan Othello'nun korkularından oluşur ve onu avlar. Iago, Othello'nun şeytanına kulak vermesine sebep olur. İçinden geçen tüm şüpheleri dillendirir. Aslında Iago da kendi şeytanlarıyla meşguldür. Fakat iki adam ortak aşağılık duygusu ve öz nefret yolunda buluşurlar. İkisi de yüzleşmesi gereken yanlarıyla trajik bir biçimde yüzleşirler. Bu organik oluşumun sadece bir tarafının iyi olmak için şansı vardır. 0 da Othello'dur. Fakat o bu şansı değerlendiremeyip kendini Iago'nun nefretine bırakır.

Jung, gölgeyi oluşturan aşağılık duygusunun duygusal, özerk, takıntılı ve hatta sahiplenici bir doğası olduğunu söyler. Jung'a göre (1969: 8/9-15) bu duygusallık, bireyin bir eylemi değil aksine bireyin etkilendiği bir şeydir; bu duygulanımın etkileri ise uyumun en zayıf olduğu durumlarda ortaya çıkmaktadır. Othello da özellikle çaba harcayarak uyum gösterdiği toplum yaşantısında bastırdığı duygularını, en zayıf anında Iago sayesinde ortaya dökmüştür. $\mathrm{Bu}$ duyguların etkileri de kendisi ve hayatındakiler için yıkıcı olmuştur. Ruhunun derinlerinde olan ilkel duyguları, 
kıskançlıkla beslenip toplumla olan anlaşmalı uyumuna bir anda son vermiştir. 0 noktadan sonra kendisine bir sebep araması doğal olacaktır. Desdemona, tüm bunların sebebi gibi gözükmektedir. Desdemona'yla birleşmenin değil onu öldürmenin dengeyi sağlayacağına inanmıştır. Jung'un kolektif bilinçdışı kuramına göre her insanın ruhsal süreçlerini yaşayıp tamamlanmaya ihtiyacı vardır. Gölge egonun yüzleşmesi ve büyüyüp gelişmesi gereken ilkel yoldaşıdır. Fakat Othello, egosunu (bilinç) ve gölgesini (bilinçdışı) bütünleştirip bireyleşme sürecini tamamlayamadan yaşamına kendi eliyle son vermiştir.

\section{Notlar}

1 Kabile kelimesi İngilizce 'tribe' kelimesiyle karşılanır. 'Tribe', aynı meslek ya da ilgi alanına mensup kişiler anlamına da gelmektedir.

\section{Kaynakça}

Abrams, J., Zweig, C. (Editörler). (1990). Meeting The Shadow, New York: Penguin Group.

Aranson, Alex (1973). Psyche\&Symbol in Shakespeare. Indiana UP: Bloomington.

Bodkin, Maud (1934). Archetypal Patterns in Poetry: Psychological Studies of Imagination, London: Oxford UP.

Boose, Lynda E. (1975). “Othello's handkerchief: 'The Recognisance and the Pledge of Love", English Literary Renaissance (5): 360-374.

Feldman, Abraham, Bronson (1952). “Othello's Obsession”. American Imago (9): 147-164).

Fike, Matthew (2005). "The Primitive in Othello: A Post-Jungian Reading”. Journal of Jungian Scholarly Studies Vol (1)4: 1-26.

Fiedler, Leslie, A. (1972). The Stranger in Shakespeare. New York: Stein and Day.

Frey-Rohn, L. . (1965). From Freud to Jung. Boston: Shambala.

Hunter, G.K. (1967). “Othello and Colour Prejudice”. Proceedings of the British Academy (53): 139-163.

Johnson, Robert, A. (1993). Owning Your Own Shadow, New York: HarperCollins Publishers.

Jung, C.G., Memories, Dreams, Reflections. ([1946] 1963). New York: Vintage Books..

“Two Essays on Analytical Psychology”. (1966). N.J. : Princeton University. "Aion: Researches into the Phenomenology of the Self", Collected Works of C.G. Jung Vol. 9 (Part II). (1969). N.J.: Princeton University Press.

“Psychological Types”. ([1921] 1971). Adler, G., Hull, R.F.C. (Editörler). Collected Works Vol. 6. N.J.: Princeton University Press.

"The Symbolic Life”. (1976). Adler, G., Hull, R.F.C. (Editörler). Collected Works Vol. 18. N.J.: Princeton University Press.

"The Fight With The Shadow". Adler, G., Hull, R.F.C. (Editörler). (1970). Collected Works Vol. 10. N.J.: Princeton University Press

"Dream Analysis: Notes of the Seminar Given in 1928-1930". (1984).

McGuire, W. (ed.). N.J.: Princeton.

Nelson, T.G.E., and Charles Haines (1983). “Othello's Unconsummated Marriage”. Essays in Criticism (33): 1-18.

Rogers-Gardber, B. (1992). Jung and Shakespeare. Illinois: Chiron Publications.

Rudnytsky, Peter L. (1985). "The Purloined handkerchief in Othello". The Psychoanalytic Study of Literature. Ed. Joseph Reppen and Maurice Charney. Hillsdale NJ: Analytic. (169-90).

Shakespeare, W. (2013). Othello. (çev. Özdemir Nutku). İstanbul: İş Bankası Kültür Yayınları.

Van der Post, L. .(1988). Walk with a White Bushman. London: Penguin.

Walker, S. F. .(1995). Jung and Jungians on Myth. New York: Garland Publishing. 